OPEN ACCESS

Edited by:

Miguel Luiz Batista Júnior, Boston Medical Center, United States

Reviewed by:

Aisha Rasool,

Tufts Medical Center, United States Emmanouella Magriplis, Agricultural University of Athens, Greece

${ }^{*}$ Correspondence:

Feng Liu

liufeng_dr@163.com

Specialty section:

This article was submitted to Clinical Nutrition,

a section of the journal

Frontiers in Nutrition

Received: 20 February 2021

Accepted: 20 May 2021

Published: 14 June 2021

Citation:

Wang L, Hou Y, Meng D, Yang L, Meng $X$ and Liu $F$ (2021) Vitamin B12 and Folate Levels During Pregnancy and Risk of Gestational Diabetes

Mellitus: A Systematic Review and Meta-Analysis. Front. Nutr. 8:670289.

doi: 10.3389/fnut.2021.670289

\section{Vitamin B12 and Folate Levels During Pregnancy and Risk of Gestational Diabetes Mellitus: A Systematic Review and Meta-Analysis}

\author{
Li Wang, Yanping Hou, Dexia Meng, Li Yang, Xiang Meng and Feng Liu* \\ Department of Obstetrics, Zaozhuang Maternal and Child Health Hospital, Zaozhuang, China
}

Background: The role of vitamin B12 and folate levels with risk of gestational diabetes mellitus (GDM) is unclear. The purpose of the current study was to conduct a systematic review and meta-analysis for assessing the relationship between vitamin B12 and folate concentrations during pregnancy and the risk of GDM.

Methods: PubMed, Embase, CENTRAL, and Ovid databases were searched up to 10th December, 2020 for all types of studies assessing the relationship. Qualitative and quantitative analysis of data was carried out.

Results: Twelve studies were included. Pooled serum vitamin B12 concentrations were found to be significantly lower in the GDM group as compared to the non-GDM group. No such difference was noted in serum folate levels. On pooled analysis of adjusted odds ratio's for risk of GDM with red blood cell $(\mathrm{RBC})$ folate, serum folate, and vitamin B12 as continuous variables, no significant relationship was seen. On qualitative analysis, studies reported higher RBC folate levels with a significantly increased risk of GDM. Majority studies reported no relationship between serum folate and risk of GDM. Four of six studies reported a lowered risk of GDM with higher or normal vitamin B12 levels.

Conclusion: The association between vitamin B12 and folate levels during pregnancy and the risk of GDM is unclear. Limited number of studies indicate increased risk of GDM with higher RBC folate levels, but majority studies found no association between serum folate and risk of GDM. Based on available studies, the association between the risk of GDM with vitamin B12 deficiency is conflicting. There is a need for further large-scale studies from different regions worldwide to strengthen current evidence.

Keywords: gestational diabetes, pregnancy, hyperglycemia, nutrition, insulin resistance

\section{INTRODUCTION}

Gestational diabetes mellitus (GDM) is a common disorder during pregnancy affecting around $12.9 \%$ of pregnant females around the world (1). The disease is characterized by new-onset impaired glucose tolerance and insulin resistance during pregnancy which can lead to several adverse maternal and neonatal outcomes $(2,3)$. Women with GDM are at higher risk of preeclampsia, cesarean section, and 
post-partum diabetes mellitus while neonates have an increased risk of obesity and diabetes mellitus at a later age $(3,4)$. Therefore, recognition and modification of potential risk factors for GDM can significantly impact both maternal and neonatal health.

In recent years, the role of lifestyle and dietary modification in the prevention of GDM has been recognized (5). Amongst dietary factors, folate and vitamin $\mathrm{B} 12$ are essential nutrients required in early pregnancy, which are metabolically interlinked in one-carbon metabolism. The two are necessary for DNA methylation and production of nucleotides which in turn are needed for increased cellular replication and fetal growth (6). Specifically, folate is the donor of one-carbon units for the remethylation of homocysteine to methionine and then to S-adenosylmethionine (6). Folate along with Vitamin B12 as cofactor is necessary to maintain normal levels of homocysteine, as high levels of homocysteine are known to cause several pregnancy complications owing to its pro-inflammatory effect (7). Thus, both these nutrients (folate and Vitamin B12) are closely intertwined in this important metabolic function and deficiency of any of the two can potentially lead to pregnancy-related complications (7).

Folate supplements are recommended before and during early pregnancy for the prevention of neural tube defects (8). Supplemental folate intake to decrease nutritional deficiency has been made mandatory in more than 50 countries worldwide (9). With increased intake of folate, concerns about the negative implications of high folate levels have been raised. In the past decade, research has indicated a contrasting relationship between folate intake and GDM risk. Zhu et al. (10) in a prospective cohort study involving 1,938 females demonstrated a 2.25 times increased risk of GDM in women consuming daily folate supplements in the first trimester of pregnancy. On the other hand, in a recent study of 14,553 women, $\mathrm{Li}$ et al. (11) indicated a lowered risk of GDM in women with higher habitual intakes of supplemental folate before pregnancy.

Such contrasting data exists for the association between vitamin B12 and GDM as well. Studies have implicated lower vitamin B12 levels in pregnancy with adverse outcomes like obesity, insulin resistance, and GDM (12). On the other hand, a recent Chinese study on 1,058 pregnant females demonstrated an increased risk of GDM with higher vitamin B12 levels (13).

In this context, there is a lack of clarity on the association between vitamin B12 and folate levels during pregnancy and the risk of GDM. To the best of our knowledge, only one systematic review and meta-analysis has been published to date assessing the relationship between vitamin B12 and GDM risk (12). The review, however, did not assess the association of folate levels and could include only six studies. Therefore, the purpose of the current review was to systematically search the literature for studies assessing the relationship between vitamin $\mathrm{B} 12$ and folate concentrations during pregnancy and the risk of GDM and carry out a qualitative and quantitative analysis of data to present high-level evidence to patients as well as clinicians.

\section{MATERIALS AND METHODS}

\section{Inclusion Criteria}

The review was conducted as per the PRISMA statement (Preferred Reporting Items for Systematic Reviews and Metaanalyses) (14). Inclusion criteria for the review were as follows:

(1) Prospective or retrospective cohort studies and crosssectional studies reporting the incidence or prevalence of GDM based on concentrations of vitamin B12 and/or folate in pregnant women (2) Studies were to compare concentrations of vitamin B12 and/or folate in GDM patients with a control group of nonGDM women. (3) Studies assessing both serum folate, and red blood cell (RBC) folate levels were eligible for inclusion.

The following studies were excluded: (1) Studies reporting risk of GDM based on the intake of folate or vitamin B12 supplements and not on biochemical values. (2) Studies assessing the risk of GDM based on any other vitamins. (3) Studies without a control group. (4) Review articles, non-English language studies, case series and case reports. For studies reporting duplicate or overlapping data, the study with the larger sample size was to be included.

\section{Search Strategy}

An electronic search was conducted in the PubMed, Embase, CENTRAL, and Ovid databases to identify relevant publications. All databases were screened from inception to 10th December, 2020. The search was conducted by two reviewers independent of each other. Keywords used in different combinations were: "vitamin B12," "folic acid," "folate," "gestational diabetes," "gestational," and "hyperglycemia." Supplementary Table 1 demonstrates the search strategy. Every search result was evaluated by the two reviewers independently, initially by their titles and abstracts and then by full texts of relevant publications. All full-texts were reviewed based on the inclusion and exclusion criteria and the article satisfying all the criteria was finally selected for this review. Any disagreements were resolved by discussion. To avoid any missed studies, the bibliography of included studies were hand searched for any additional references.

\section{Data Extraction and Risk of Bias Assessment}

We prepared a data extraction form at the beginning of the review to extract relevant details from the studies. Details of the first author, publication year, study type, study location, sample size, age, and body mass index (BMI) of patients, testing protocol and criteria for GDM, serum folate, and vitamin B12 concentrations, and study outcomes were extracted. The outcome of interest was to assess the risk of developing GDM based on vitamin B12 and folate levels. We also compared the serum concentrations of vitamin B12 and folate between the GDM and non-GDM groups.

Since all included studies were cross-sectional or cohort studies, we assessed the quality of included studies using the risk of a bias assessment tool for non-randomized studies (RoBANS) (15). Two reviewers assessed each study for: selection of participants, confounding variables, intervention measurements, 


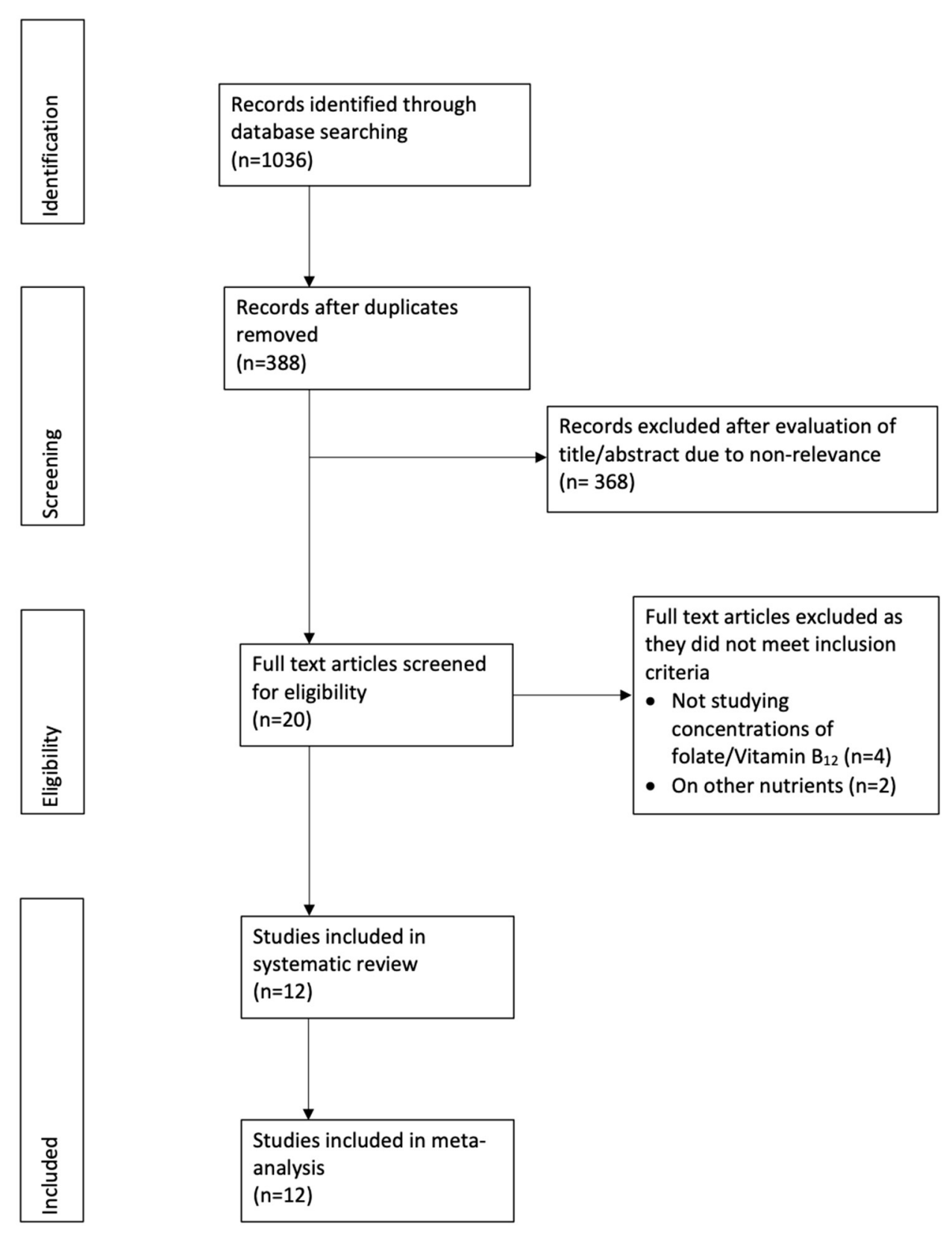

FIGURE 1 | Study flow chart.

blinding of outcome assessment, incomplete outcome data, and selective outcome reporting.

\section{Statistical Analysis}

"Review Manager" [RevMan, version 5.3; Nordic Cochrane Center (Cochrane Collaboration), Copenhagen, Denmark; 2014] was used for the meta-analysis. We initially pooled mean and standard deviation (SD) of serum concentrations of vitamin B12 and folate in the GDM and non-GDM groups to calculate the mean difference (MD) with $95 \%$ confidence intervals (CI).
For studies not reporting mean and SD values, the same was calculated from the median and interquartile range (16). We also extracted multivariable-adjusted odds ratios (OR) for the risk of developing GDM based on serum concentrations of vitamin b12, serum folate, and RBC folate levels and pooled data using the generic inverse function of the meta-analysis software. For data that could not be pooled due to heterogeneous reporting, a descriptive analysis was carried out. A meta-analysis was conducted if at least three studies reported the same outcome on a homogenous scale. A random-effects model was preferred for 
the meta-analysis. The $I^{2}$ statistic was used to assess inter-study heterogeneity. $I^{2}$ values of $25-50 \%$ represented low, values of $50-75 \%$ medium, and more than $75 \%$ represented substantial heterogeneity. Funnel plots were used to assess publication bias.

\section{RESULTS}

Figure 1 presents the study flow-chart. A total of 12 studies fulfilled the inclusion criteria and were included in the review (13, 17-27). Details of the included studies are presented in Table $\mathbf{1}$. The majority of the studies were prospective in nature. Four of the 12 studies were carried out in China, two in Turkey, while one each in the United Kingdom, India, Singapore, Italy, Poland, Australia, and New Zealand. The oral glucose tolerance test (OGTT) was used in all studies for diagnosing GDM, however, the diagnostic criteria varied. The sample size in the GDM group varied from 15 to 392 patients. The risk of bias analysis of included studies is presented in Supplementary Table 2.

\section{Meta-Analysis}

Comparing the serum folate concentration $(\mathrm{ng} / \mathrm{ml})$ between the GDM and non-GDM group, our pooled analysis indicated no difference between the study groups (MD: 0.28 95\%CI: -0.46 , $1.03 I^{2}=49 \% p=0.46$ ) (Figure 2). However, serum vitamin B12 concentrations $(\mathrm{pg} / \mathrm{ml})$ were found to be significantly lower in the GDM group as compared to the non-GDM group (MD: $-16.0595 \% \mathrm{CI}$ : $-29.77,-2.33 I^{2}=70 \% p=0.02$ ) (Figure 3). There was no evidence of publication bias in both the analyses (Supplementary Figures 1, 2).

Multivariable adjusted ORs for risk of GDM were reported by eight of the 12 included studies. Details are presented in Table 2. Six of these studies reported an association between the risk of GDM with serum folate and vitamin B12 concentrations. Three studies reported data on the risk of GDM based on RBC folate levels. Only three studies reported adjusted ORs for risk of GDM with RBC folate, serum folate, and vitamin B12 as continuous variables. Pooled analysis demonstrated no statistically significant relation between RBC folate levels and risk of GDM (OR: 1.06 95\%CI: 0.98, $1.15 I^{2}=77 \% p=$ 0.17) (Figure 4). Similarly, no significant relationship was noted between serum folate levels (OR: 1.01 95\%CI: 0.97, $1.05 I^{2}=54 \%$ $p=0.63$ ) (Figure 5) and vitamin B12 level (OR: $1.0095 \% \mathrm{CI}$ : $0.88,1.13 I^{2}=85 \% p=0.95$ ) (Figure 6) with risk of GDM. There was no evidence of publication bias in either analyses (Supplementary Figures 3-5).

\section{Descriptive Analysis-Folate Levels}

There was a wide variation in the classification of quartile ranges for defining the association between the study variables and GDM risk. Hence, a meta-analysis could not be conducted, and instead, a descriptive analysis was carried out. For RBC folate levels, all three studies reported a significantly increased risk of GDM in the highest quartiles of their respective studies. Liu et al. (27) reported 2.473 times (95\% CI: 1.013, 6.037) increased risk of GDM with RBC folate levels of $\geq 380.6 \mathrm{ng} / \mathrm{ml}$. Similarly, Chen et al. (13) reported 1.58 times (95\% CI: 1.03, 2.41 ) and Xie et al. (24) reported 2.76 times (95\% CI: 1.56, 4.89) increased risk of GDM with $\mathrm{RBC}$ folate levels of $\geq 600 \mathrm{ng} / \mathrm{ml}$ and $570.2 \mathrm{ng} / \mathrm{ml}$, respectively. Of the six studies assessing the relation between serum folate and GDM, four $(13,20,22,26)$ reported no statistically significant association between serum folate levels and risk of GDM. Li et al. (25) reported 1.98 times (95\% CI: 1, 3.90) increased risk of GDM with serum folate levels $\geq 12.2 \mathrm{ng} / \mathrm{ml}$, and Lai et al. (23) reported 1.29 times (95\% CI: $1.01,1.60)$ increased risk of GDM with an incremental increase in serum folate. Of the four studies not reporting adjusted ORs, none reported any statistically significant difference in serum folate levels between GDM and non-GDM groups. Similarly, no difference was noted in vitamin B12 levels, except for Seghieri et al. (17) which reported lower vitamin B12 levels in women with GDM.

\section{Descriptive Analysis-Vitamin B12 Levels}

Of the six studies assessing the relationship between serum vitamin B12 levels and risk of GDM, only one study reported no statistically significant relationship between the two (26). Two studies reported a statistically significant increased risk of GDM with vitamin B12 deficiency. Krishnaveni et al. (20) and Sukumar et al. (22) reported two times increased risk of GDM with vitamin B12 levels $<203.3 \mathrm{pg} / \mathrm{ml}$. In line with these studies, Lai et al. (23) reported a significantly lowered risk of GDM with a per unit increase in vitamin B12 levels. Li et al. (25) also found a significantly reduced risk of GDM with vitamin B12>234 pg/ml. Only Chen et al. (13) reported 2 times (95\% CI: 1.35, 2.96) increased risk of GDM with vitamin B12 > $429 \mathrm{pg} / \mathrm{ml}$.

\section{DISCUSSION}

Folate is an extremely important micronutrient for pregnant females due to its role in preventing birth defects (28). Given the evidence, the USA Public Health Service recommends daily supplementation of $0.4-0.8 \mathrm{mg}$ of folic acid for all pregnant females (29). Studies have indicated that food fortification with folates significantly reduces the incidence of neural tube defects (28). However, with the widespread consumption of folate, especially in pregnant females, the potential adverse risks of high folate levels on both the mother and the child have caused concerns. Yajnik et al. (30) have demonstrated that high $\mathrm{RBC}$ folate and low vitamin B12 levels in mothers during pregnancy result in an increased risk of insulin resistance and higher adiposity in the offspring. Similar concerns have been raised for the risk of maternal GDM with preconceptional and periconceptional folate supplements but with conflicting results $(10,11)$. The contradictory results in literature can be partially attributed to the difference in timing of folate supplements, the dosage as well as on patient adherence. Furthermore, folate metabolism can vary amongst individuals leading to varying serum folate levels (31). Thus, it is better to assess the risk of GDM based on actual body folate concentrations rather than the intake of folate supplements. Thus, we excluded studies reporting associations between nutritional supplements and risk of GDM without measuring maternal folate or vitamin B12 levels.

Studies included in our review measured both sera as well as RBC folate levels. While serum folate levels are easily altered 
TABLE 1 | Characteristics of included studies.

\begin{tabular}{|c|c|c|c|c|c|c|c|c|c|c|}
\hline References & Location & Type & $\begin{array}{l}\text { Test for } \\
\text { GDM }\end{array}$ & Criteria for GDM & Testing period & $\begin{array}{l}\text { Testing period } \\
\text { for folate, } \\
\text { vitamin B12 }\end{array}$ & Sample size & Mean age (years) & $\begin{array}{l}\text { Mean BMI } \\
\left(\mathrm{kg} / \mathrm{m}^{2}\right)\end{array}$ & $\begin{array}{l}\text { Outcomes } \\
\text { measured }\end{array}$ \\
\hline \multirow[t]{2}{*}{$\begin{array}{l}\text { Jankovic- } \\
\text { Karasoulos et al. } \\
\text { (26) }\end{array}$} & $\begin{array}{l}\text { Australia and } \\
\text { New Zealand }\end{array}$ & $\begin{array}{l}\text { Prospective } \\
\text { cohort }\end{array}$ & $\begin{array}{l}\text { Fasting } \\
\text { glucose or } \\
\text { OGTT }\end{array}$ & $\begin{array}{l}\mathrm{FPG} \geq 5.1 \mathrm{mmol} / \mathrm{L} \text { or following } \\
\text { an OGT, a } 2-\mathrm{h} \text { level of } \geq 8.5 \\
\mathrm{mmol} / \mathrm{L}\end{array}$ & Around 26 weeks & $\begin{array}{l}15 \pm 1 \text { week of } \\
\text { gestation }\end{array}$ & GDM: 33 & $N R$ & NR & $\begin{array}{l}\text { Serum folate, } \\
\text { vitamin B12 }\end{array}$ \\
\hline & & & & & & & Control: 111 & & & \\
\hline \multirow[t]{2}{*}{ Liu et al. (27) } & China & $\begin{array}{l}\text { Prospective } \\
\text { cohort }\end{array}$ & $75 \mathrm{~g}$ OGTT & $\begin{array}{l}\mathrm{FPG} \geq 5.1 \mathrm{mmol} / \mathrm{L}, 1-\mathrm{h} \text { plasma } \\
\text { glucose } \geq 10.0 \mathrm{mmol} / \mathrm{L} \text {, and } 2-\mathrm{h} \\
\text { plasma glucose } \geq 8.5 \mathrm{mmol} / \mathrm{L}\end{array}$ & 24-28 weeks & 1st trimester & GDM: 67 & $30.5 \pm 4$ & $24.3 \pm 3.6$ & RBC folate \\
\hline & & & & & & & Control: 299 & $28.9 \pm 3.5$ & $22.4 \pm 3.6$ & \\
\hline Chen et al. (13) & China & $\begin{array}{l}\text { Prospective } \\
\text { cohort }\end{array}$ & $75 \mathrm{~g}$ OGTT & $\begin{array}{l}\mathrm{FPG} \geq 5.1 \mathrm{mmol} / \mathrm{L}, 1 \text {-h plasma } \\
\text { glucose } \geq 10.0 \mathrm{mmol} / \mathrm{L} \text {, and } 2-\mathrm{h} \\
\text { plasma glucose } \geq 8.5 \mathrm{mmol} / \mathrm{L}\end{array}$ & 24-28 weeks & $\begin{array}{l}\text { 9-13 weeks of } \\
\text { gestation }\end{array}$ & $\begin{array}{l}\text { Total: 1,058 (180 } \\
\text { with GDM) }\end{array}$ & $30.2 \pm 4$ & $21 \pm 2.8$ & $\begin{array}{l}\text { RBC folate, serum } \\
\text { folate, vitamin B12 }\end{array}$ \\
\hline \multirow[t]{2}{*}{ Xie et al. (24) } & China & $\begin{array}{l}\text { Prospective } \\
\text { cohort }\end{array}$ & $75 \mathrm{~g}$ OGTT & $\begin{array}{l}\mathrm{FPG} \geq 5.5 \mathrm{mmol} / \mathrm{L}, 2 \text {-h plasma } \\
\text { glucose } \geq 8 \mathrm{mmol} / \mathrm{L}\end{array}$ & 24-28 weeks & 2nd trimester & GDM: 392 & $29 \pm 3.2$ & $24.3 \pm 3.1$ & RBC folate \\
\hline & & & & & & & Control: 1,890 & $27.9 \pm 3.2$ & $23.2 \pm 2.7$ & \\
\hline Li et al. (25) & China & $\begin{array}{l}\text { Prospective } \\
\text { cohort }\end{array}$ & $75 \mathrm{~g}$ OGTT & $\begin{array}{l}\mathrm{FPG} \geq 5.1 \mathrm{mmol} / \mathrm{L}, 1-\mathrm{h} \text { plasma } \\
\text { glucose } \geq 10.0 \mathrm{mmol} / \mathrm{L} \text {, and } 2-\mathrm{h} \\
\text { plasma glucose } \geq 8.5 \mathrm{mmol} / \mathrm{L}\end{array}$ & 24-28 weeks & 24-28 weeks & $\begin{array}{l}\text { Total: } 406 \text { (90 with } \\
\text { GDM) }\end{array}$ & $29.4 \pm 4.5$ & NR & $\begin{array}{l}\text { Serum folate, } \\
\text { vitamin B12 }\end{array}$ \\
\hline Lai et al. (23) & Singapore & $\begin{array}{l}\text { Prospective } \\
\text { cohort }\end{array}$ & $75 \mathrm{~g}$ OGTT & $\begin{array}{l}\text { FPG } \geq 7 \mathrm{mmol} / \mathrm{L}, 2-\mathrm{h} \text { plasma } \\
\text { glucose } \geq 7.8 \mathrm{mmol} / \mathrm{L}\end{array}$ & 26-28 weeks & 26-28 weeks & $\begin{array}{l}\text { Total: } 913 \text { (164 } \\
\text { with GDM) }\end{array}$ & $N R$ & NR & $\begin{array}{l}\text { Serum folate, } \\
\text { vitamin B12 }\end{array}$ \\
\hline \multirow[t]{2}{*}{ Sukumar et al. (22) } & UK & $\begin{array}{l}\text { Retrospective } \\
\text { cohort }\end{array}$ & $75 \mathrm{~g} \mathrm{OGTT}$ & $\begin{array}{l}\mathrm{FPG} \geq 6.1 \mathrm{mmol} / \mathrm{L}, 2 \text {-h plasma } \\
\text { glucose } \geq 7.8 \mathrm{mmol} / \mathrm{L}\end{array}$ & 26-28 weeks & 2nd trimester & GDM: 143 & $31.4 \pm 5.8$ & $31.7 \pm 7$ & $\begin{array}{l}\text { Serum folate, } \\
\text { vitamin B12 }\end{array}$ \\
\hline & & & & & & & Control: 201 & $29.6 \pm 5.9$ & $26.7 \pm 7.1$ & \\
\hline $\begin{array}{l}\text { Krishnaveni et al. } \\
\text { (20) }\end{array}$ & India & $\begin{array}{l}\text { Retrospective } \\
\text { cohort }\end{array}$ & $100 \mathrm{~g}$ OGTT & $\begin{array}{l}\mathrm{FPG} \geq 7 \mathrm{mmol} / \mathrm{L}, 2-\mathrm{h} \text { plasma } \\
\text { glucose } \geq 11.1 \mathrm{mmol} / \mathrm{L}\end{array}$ & 30 weeks & 30 weeks & $\begin{array}{l}\text { Total: } 519 \text { (35 with } \\
\text { GDM) }\end{array}$ & $24(21-26)^{*}$ & $23.5(20.5-26.9)^{\star}$ & $\begin{array}{l}\text { Serum folate, } \\
\text { vitamin B12 }\end{array}$ \\
\hline \multirow[t]{2}{*}{$\begin{array}{l}\text { Idzior- Waluś et al. } \\
(21)\end{array}$} & Poland & $\begin{array}{l}\text { Prospective } \\
\text { cohort }\end{array}$ & $75 \mathrm{~g} \mathrm{OGTT}$ & $\begin{array}{l}\mathrm{FPG} \geq 6.1 \mathrm{mmol} / \mathrm{L}, 2 \text {-h plasma } \\
\text { glucose } \geq 7.8 \mathrm{mmol} / \mathrm{L}\end{array}$ & 26-32 weeks & 26-32 weeks & GDM: 44 & $30.5 \pm 6.6$ & $27.8 \pm 5.2$ & $\begin{array}{l}\text { Serum folate, } \\
\text { vitamin B12 }\end{array}$ \\
\hline & & & & & & & Control: 17 & $26.3 \pm 4$ & $25.6 \pm 3.4$ & \\
\hline \multirow[t]{2}{*}{ Guven et al. (19) } & Turkey & $\begin{array}{l}\text { Cross- } \\
\text { sectional }\end{array}$ & $100 \mathrm{~g}$ OGTT & $\begin{array}{l}\text { Two or more of the following } \\
\text { plasma values must be met or } \\
\text { exceeded: FPG } 95 \mathrm{mg} / \mathrm{dl}, 1 \mathrm{~h} \\
180 \mathrm{mg} / \mathrm{dl}, 2 \mathrm{~h} 155 \mathrm{mg} / \mathrm{dl} \text { and } \\
3 \mathrm{~h} 140 \mathrm{mg} / \mathrm{dl}\end{array}$ & 24-28 weeks & 24-28 weeks & GDM: 30 & $30 \pm 4.3$ & $29.2 \pm 4.1$ & $\begin{array}{l}\text { Serum folate, } \\
\text { vitamin B12 }\end{array}$ \\
\hline & & & & & & & Control: 147 & $28.6 \pm 3.4$ & $27.9 \pm 2.8$ & \\
\hline \multirow[t]{2}{*}{ Tarim et al. (18) } & Turkey & $\begin{array}{l}\text { Prospective } \\
\text { cohort }\end{array}$ & $50 \mathrm{~g} \mathrm{OGTT}$ & $\begin{array}{l}\text { Two or more of the following } \\
\text { plasma values must be met or } \\
\text { exceeded: FPG } 95 \mathrm{mg} / \mathrm{dll}, 1 \mathrm{~h} \\
180 \mathrm{mg} / \mathrm{dl}, 2 \mathrm{~h} 155 \mathrm{mg} / \mathrm{dl} \text { and } \\
3 \mathrm{~h} 140 \mathrm{mg} / \mathrm{dl}\end{array}$ & 24-28 weeks & 24-28 weeks & GDM: 28 & $32 \pm 4$ & $27.1 \pm 2.1$ & $\begin{array}{l}\text { Serum folate, } \\
\text { vitamin B12 }\end{array}$ \\
\hline & & & & & & & Control: 210 & $26.8 \pm 4.4$ & $25.2 \pm 2$ & \\
\hline \multirow[t]{2}{*}{ Seghieri et al. (17) } & Italy & $\begin{array}{l}\text { Cross- } \\
\text { sectional }\end{array}$ & $100 \mathrm{~g}$ OGTT & NR & 24-28 weeks & 24-28 weeks & GDM: 15 & $34.6 \pm 3.1$ & $26.7 \pm 3.2$ & $\begin{array}{l}\text { Serum folate, } \\
\text { vitamin B12 }\end{array}$ \\
\hline & & & & & & & Control: 78 & $32.3 \pm 3.7$ & $26.3 \pm 3.7$ & \\
\hline
\end{tabular}

$\mathrm{FPG} \geq 7 \mathrm{mmol} / \mathrm{L}, 2$-h plasma glucose $\geq 7.8 \mathrm{mmol} / \mathrm{L}$

Krishnaveni et al. Ind

Idzior- Waluś et al. Poland

Guven et al. (19) Turk
GDM, gestation diabetes mellitus; OGTT, oral-glucose tolerance test; NA, Not available; FPG, fasting plasma glucose; $h$, hour.
${ }^{*}$ Median (interquartile). 


\begin{tabular}{|c|c|c|c|c|c|c|c|c|c|c|}
\hline \multirow[b]{2}{*}{ Study or Subgroup } & \multicolumn{3}{|c|}{ GDM } & \multicolumn{3}{|c|}{ nGDM } & \multirow[b]{2}{*}{ Weight } & \multirow{2}{*}{$\begin{array}{l}\text { Mean Difference } \\
\text { IV, Random, } 95 \% \mathrm{CI}\end{array}$} & \multirow[b]{2}{*}{ Year } & \multirow{2}{*}{$\begin{array}{l}\text { Mean Difference } \\
\text { IV, Random, 95\% CI }\end{array}$} \\
\hline & Mean & SD & Total & Mean & SD & Total & & & & \\
\hline Jankovic-Karasoulos 2020 & 16.6 & 3.5 & 33 & 14.1 & 4.9 & 111 & $13.3 \%$ & $2.50[1.00,4.00]$ & 2020 & \\
\hline Liu 2020 & 9.1 & 3.3 & 67 & 9 & 2.6 & 299 & $21.1 \%$ & $0.10[-0.74,0.94]$ & 2020 & - \\
\hline Li 2019 & 10.4 & 6.6 & 90 & 9.6 & 5.95 & 316 & $13.2 \%$ & $0.80[-0.71,2.31]$ & 2019 & \\
\hline Sukumar 2016 & 10.2 & 6.9 & 143 & 10.2 & 6.6 & 201 & $13.8 \%$ & $0.00[-1.45,1.45]$ & 2016 & \\
\hline Idzior-Walus 2008 & 11.2 & 6 & 44 & 11.1 & 5.9 & 17 & $4.3 \%$ & $0.10[-3.22,3.42]$ & 2008 & \\
\hline Guven 2006 & 6.34 & 2.25 & 30 & 6.7 & 3.2 & 147 & $19.6 \%$ & $-0.36[-1.32,0.60]$ & 2006 & $\rightarrow-$ \\
\hline Tarim 2004 & 9.97 & 4.05 & 28 & 11.09 & 4.86 & 210 & $12.1 \%$ & $-1.12[-2.76,0.52]$ & 2004 & 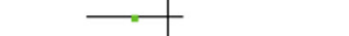 \\
\hline Seghieri 2003 & 14.7 & 7.9 & 15 & 13.8 & 7.3 & 78 & $2.7 \%$ & $0.90[-3.41,5.21]$ & 2003 & \\
\hline Total $(95 \% \mathrm{Cl})$ & & & 450 & & & 1379 & $100.0 \%$ & $0.28[-0.46,1.03]$ & & \\
\hline \multicolumn{10}{|c|}{$\begin{array}{l}\text { Heterogeneity: } \text { Tau }^{2}=0.50 ; \mathrm{Chi}^{2}=13.65, \mathrm{df}=7(P=0.06) ; \mathrm{I}^{2}=49 \% \\
\text { Test for overall effect: } Z=0.74(P=0.46)\end{array}$} & $\begin{array}{ccccc}1 & 1 & 1 & 1 & 1 \\
-4 & -2 & 0 & 2 & 4 \\
\text { Favours } & {[\mathrm{GDM}]} & \text { Favours } & \text { [nGDM] }\end{array}$ \\
\hline
\end{tabular}

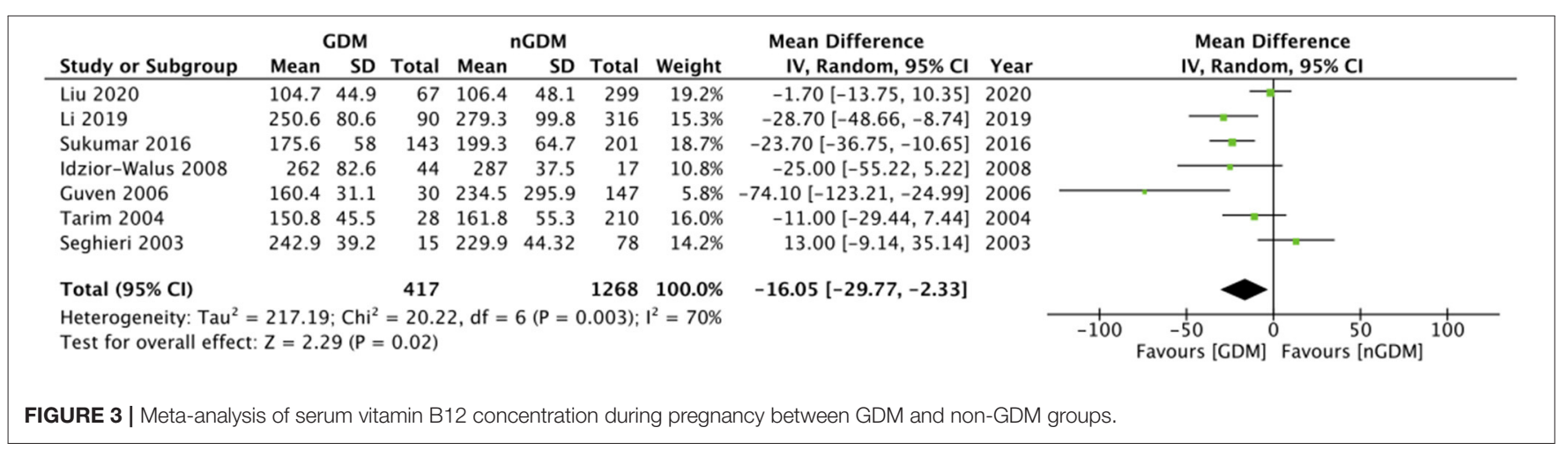

by folate intake or supplements, $\mathrm{RBC}$ folate levels correspond to long-term intake of folate supplementation or fortified foods (13, 32). WHO guidelines recommend that RBC folate concentrations be maintained above $400 \mathrm{ng} / \mathrm{ml}$ to achieve the greatest reduction of neural tube defects. However, as serum folate concentrations are rapidly altered by folate intake, no such threshold was provided for serum folate levels (33). In our analysis, we found no statistically significant difference in serum folate levels between GDM and non-GDM women. Four of the six studies reported no association between serum folate and risk of GDM. Also, on the meta-analysis of RBC folate and serum folate as continuous variables, we could not find any significant relationship between folate levels and the risk of GDM. However, all three studies measuring RBC folate levels found a significantly increased risk of GDM with higher RBC folate quartiles (ranging from $>380.6$ to $600 \mathrm{ng} / \mathrm{ml}$ ). Thus, the results indicate that higher RBC folate levels are associated with increased risk of GDM, however, the association is non-linear. Given the limited number of studies which were all conducted in a single country on a single ethnic group and the different quartile used in each study, it is not possible at this stage to provide a specific cut-off for increased risk of GDM based on RBC folate levels. Furthermore, there were several other variations in the included studies like, the difference in adjusted confounding factors, time of measurement of folate levels, the ethnicity of the population, use of folate supplements, and classification of data, all of which could have contributed to the varied results amongst studies especially for the association of serum folate levels and risk of GDM. In the two studies reporting an increased risk of GDM with serum folate levels, the effect size was small with the lower end of 95\% CI close to 1 [(25): 1; (23): 1.01]. Also, in two of the four studies reporting no relationship between serum folate and GDM, the sample size was small and this could have affected the results $(20,26)$.

Our analysis also demonstrated lower vitamin B12 levels in the GDM group as compared to the non-GDM group. Vitamin B12 deficiency is conventionally diagnosed if serum B12 levels are $<203.3 \mathrm{pg} / \mathrm{ml}$ (150 pmol/L) (34). In our review, Sukumar et al. (22) and Krishnaveni et al. (20) both demonstrated an increased risk of GDM with vitamin B12 deficiency. In concurrence with these studies, Li et al. (25) found that vitamin B12 levels higher than $234 \mathrm{pg} / \mathrm{ml}$ are associated with a significantly reduced risk of GDM. Similar results were noted by Lai et al. (23). However, contrasting results were demonstrated by Chen et al. (13), who reported higher vitamin B12 levels to be associated with an increased risk of GDM. The variation of results may be explained by the timing of serum vitamin B12 measurements in the included studies. While all four studies reporting an inverse relationship between vitamin B12 levels and risk of GDM measured B12 levels in the second or third trimester of pregnancy, Chen et al. (13) measured the same at early pregnancy (9-13 weeks). Studies indicate physiological changes of pregnancy may affect vitamin B12 requirement with a decrease in vitamin B12 levels from preconception to mid-gestation $(35,36)$. Since both vitamin B12 and folic acid are closely related to nucleic acid synthesis, methyl group generation, and conversion of homocysteine to methionine; the possibility of 
TABLE 2 | Multivariable adjusted Odds ratios from the included studies.

\begin{tabular}{ll}
\hline References & $\begin{array}{l}\text { Adjusted factors for multivariable } \\
\text { analysis }\end{array}$ \\
\hline $\begin{array}{l}\text { Jankovic-Karasoulos } \\
\text { et al. (26) }\end{array}$ & Age, BMl, smoking status \\
Liu et al. (27) & $\begin{array}{l}\text { Age, physical activity, BMl, parity, family } \\
\text { history of diabetes, use of folic acid } \\
\text { supplements, HOMA-IR, C-reactive } \\
\text { protein, hemoglobin, vitamin B12, and } \\
\text { serum homocysteine }\end{array}$
\end{tabular}

Chen et al. (13)

Xie et al. (24)

Li et al. (25)

Lai et al. (23)

Sukumar et al. (22)

Krishnaveni et al. (20)
Age, preconceptional BMl, family history of diabetes, smoking exposure, and drinking status

Age, parity, BMl at enrolment

Age, ethnicity, education, parity, pre-pregnancy BMI, and family history of diabetes, folate (or vitamin B12)

Age, ethnicity, education, income, smoking, alcohol intake, physical activity, pre-pregnancy BMI, parity, family history of diabetes, and previous occurrence of GDM, folate (or vitamin $\mathrm{B}_{6}$ and $\mathrm{B}_{12}$ )

Age, parity, ethnic origin, smoking, gestation of bloods, and serum folate (or vitamin B12)

Age, socioeconomic status, religion, parity and family history of diabetes

\section{Outcome}

\section{Vitamin B12}

Every 50-unit increase

Serum folate

Every 5-unit increase

$\mathrm{RBC}$ folate

Q1 $<224.6 \mathrm{ng} / \mathrm{ml}$

Q2 224.6-285.9 ng/ml

Q3 285.9-380,6 $\mathrm{ng} / \mathrm{ml}$

Q4 $\geq 380.6 \mathrm{ng} / \mathrm{ml}$

As continuous variable

$\mathrm{RBC}$ folate

Q1<400 ng/ml

Q2 400-600 ng/ml

Q3 $\geq 600 \mathrm{ng} / \mathrm{ml}$

As continuous variable

Serum folate

Q1<13.9 ng/ml

Q2 13.9-16 ng/ml

Q3 $\geq 16 \mathrm{ng} / \mathrm{ml}$

As continuous variable

Vitamin B12

Q1<330 pg/ml

Q2 330-429 pg/ml

Q3 $\geq 429 \mathrm{pg} / \mathrm{ml}$

As continuous variable

RBC folate

Q1<399.8ng/ml

Q2 399.8-570.2 ng/ml

Q3 $\geq 570.2 \mathrm{ng} / \mathrm{ml}$

As continuous variable

Serum folate

Q1 $<6.9 \mathrm{ng} / \mathrm{ml}$

Q2 6.9-12.2 ng/ml

Q3 $\geq 12.2 \mathrm{ng} / \mathrm{ml}$

Vitamin B12

Q1<234 pg/ml

Q2 234-306 pg/ml

Q3 $\geq 306 \mathrm{pg} / \mathrm{ml}$

Serum folate

As continuous variable

Vitamin B12

As continuous variable

Serum folate

$3.1-18.7 \mathrm{ng} / \mathrm{ml}$

$<3.1 \mathrm{ng} / \mathrm{ml}$

Vitamin B12

203.3-489 pg/ml

$<203.3 \mathrm{pg} / \mathrm{ml}$

Serum folate

As continuous variable

Vitamin $B_{12}$

203.3-489 pg/ml

$<203.3 \mathrm{pg} / \mathrm{ml}$

As continuous variable
Adjusted OR (95\% CI)

$0.99(0.83-1.18)$

$1.22(0.93-1.59)$

Reference

$1.354(0.530-3.456)$

$1.374(0.546-3.455)$

$2.473(1.013-6.037)$

1.001 (1.000-1.002)

Reference

$1.39(0.94-2.04)$

$1.58(1.03-2.41)$

$1.07(0.99-1.15)$

Reference

$0.91(0.58-1.44)$

$1.36(0.94-1.99)$

$1.01(0.97-1.05)$

Reference

$1.49(0.95-2.33)$

2 (1.35-2.96)

$1.14(1.04-1.24)$

Reference

$2.17(1.20-3.95)$

$2.76(1.56-4.89)$

$1.16(1.03-1.30)$

Reference

$1.12(0.59-2.13)$

$1.98(1.0-3.90)$

Reference

$0.51(0.27-0.95)$

$0.30(0.15-0.60)$

$1.29(1.01,1.60)$

$0.81(0.68,0.97)$

Reference 0.89

$(0.07,11.38)$

Reference 2.05 (1.03, 4.10)

$1.0(0.99,1.0)$

Reference

$2.0(1.1,3.6)$

$1.0(0.99,1.0)$

OR, Odds ratio; Cl, confidence interval; Q, quartile; HOMA-IR, Homeostasis model assessment- insulin resistance; BMI, Body mass index. 


\begin{tabular}{|c|c|c|c|c|c|c|c|c|c|c|}
\hline Study or Subgroup & log[Odds Ratio] & SE & $\begin{array}{l}\text { GDM } \\
\text { Total }\end{array}$ & $\begin{array}{c}\text { nGDM } \\
\text { Total }\end{array}$ & Weight & $\begin{array}{c}\text { Odds Ratio } \\
\text { IV, Random, } 95 \% \mathrm{CI}\end{array}$ & Year & $\begin{array}{l}\text { Odds } \\
\text { IV, Randon }\end{array}$ & $\begin{array}{l}\text { Ratio } \\
\text { m, } 95 \% \mathrm{Cl}\end{array}$ & \\
\hline Xie 2019 & 0.1484 & 0.0606 & 392 & 1890 & $22.8 \%$ & $1.16[1.03,1.31]$ & 2019 & & $\longrightarrow$ & \\
\hline Chen 2020 & 0.0677 & 0.0396 & 180 & 878 & $31.9 \%$ & $1.07[0.99,1.16]$ & 2020 & & $\rightarrow-$ & \\
\hline \multirow{2}{*}{\multicolumn{8}{|c|}{$\begin{array}{l}\text { Heterogeneity: } \text { Tau }^{2}=0.00 ; \mathrm{Chi}^{2}=8.75, \mathrm{df}=2(P=0.01) ; \mathrm{I}^{2}=77 \% \\
\text { Test for overall effect: } \mathrm{Z}=1.36(\mathrm{P}=0.17)\end{array}$}} & & & \\
\hline & & & & & & & & $\begin{array}{cc}0.7 & 0.85 \\
& \text { Favours [GDM] }\end{array}$ & 1.2 & 1.5 \\
\hline
\end{tabular}

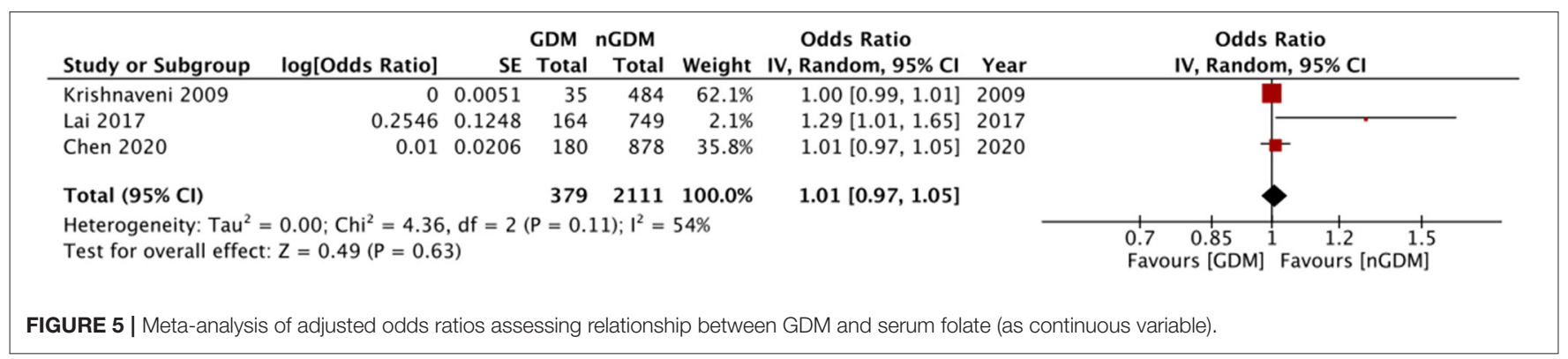

\begin{tabular}{|c|c|c|c|c|c|c|c|c|c|c|}
\hline Study or Subgroup & log[Odds Ratio] & SE & $\begin{array}{l}\text { GDM } \\
\text { Total }\end{array}$ & $\begin{array}{l}\text { nGDM } \\
\text { Total }\end{array}$ & Weight & $\begin{array}{c}\text { Odds Ratio } \\
\text { IV, Random, } 95 \% \mathrm{CI}\end{array}$ & Year & $\begin{array}{r}\text { Odds R } \\
\text { IV, Random }\end{array}$ & $\begin{array}{l}\text { Ratio } \\
\mathrm{m}, 95 \% \mathrm{Cl}\end{array}$ & \\
\hline Lai 2017 & -0.2107 & 0.0893 & 164 & 749 & $23.4 \%$ & $0.81[0.68,0.96]$ & 2017 & $\rightarrow-$ & & \\
\hline \multirow{2}{*}{\multicolumn{6}{|c|}{$\begin{array}{l}\text { Heterogeneity: } \text { Tau }^{2}=0.01 ; \mathrm{Chi}^{2}=13.37, \mathrm{df}=2(\mathrm{P}=0.001) ; \mathrm{I}^{2}=85 \% \\
\text { Test for overall effect: } Z=0.06(P=0.95)\end{array}$}} & $1.00[0.88,1.13]$ & & & & \\
\hline & & & & & & & 0.2 & $\begin{array}{c}0.5 \\
\text { Favours [GDM] }\end{array}$ & $\begin{array}{lc}1 & 1 \\
\text { Favours [nGDM] }\end{array}$ & 5 \\
\hline
\end{tabular}

one micronutrient confounding the effects of another cannot be ruled out (13). Important to note is that three of the four studies demonstrating a higher risk of GDM with low vitamin B12 reported adjusted ORs with folate as a dependent variable.

The mechanism of increased risk of GDM with folate and vitamin B12 imbalance is, however, unclear. One explanation is high folate aggravates the effects of vitamin B12 deficiency, which in turn impairs DNA synthesis particularly mitochondrial DNA, leading to the development of insulin resistance $(20,37)$. Secondly, high levels of unmetabolized serum folate are known to reduce the cytotoxicity of natural killer cells (38). The reduction of cytotoxicity has also been implicated in the pathogenesis of GDM (39).

Our study has some limitations. Firstly, a limited number of studies were available for a meta-analysis. Pooled analysis for $\mathrm{RBC}$ folate, serum folate, and serum vitamin B12 as continuous variables could include just three studies. Due to the difference in quartiles in the included studies, only a descriptive analysis could be carried out. Four studies did not report adjusted ORs for risk of GDM. Furthermore, there was wide variation amongst the studies in the factors adjusted in the multi-variable analysis. Overall, age, parity, vitamin B12/folate levels and body mass index were the most common factors adjusted but were not coherent across studies. Such differences could have influenced the outcomes of individual studies. Secondly, there were wide variations in the included studies about the time of testing and criteria for the diagnosis of GDM which could have skewed results. Thirdly, the majority of the included studies included only a small number of GDM patients $(<50)$. Lack of adequate power may have influenced the results. Lastly, the majority of studies were from Asian countries and generalization of the findings to other ethnic populations requires further research.

To conclude, the association between vitamin B12 and folate levels during pregnancy and the risk of GDM is not very clear. Unadjusted data is indicative of lower vitamin B12 levels in women with GDM as compared to their healthy counterparts, but folate levels are not different. Limited number of studies indicate increased risk of GDM with higher RBC folate levels, but majority 
studies found no association between serum folate and risk of GDM. Based on available studies, the association between the risk of GDM with vitamin B12 deficiency is conflicting. There is a need for further large-scale studies from different regions worldwide to strengthen current evidence.

\section{DATA AVAILABILITY STATEMENT}

Publicly available datasets were analyzed in this study. This data can be found here: PubMed, Embase, CENTRAL, and Ovid databases.

\section{AUTHOR CONTRIBUTIONS}

LW conceived, designed the study, and wrote the paper. $\mathrm{YH}, \mathrm{DM}, \mathrm{LY}$, and XM were involved in literature search, data collection, and analyzed the data. FL reviewed and edited the manuscript. All authors read and approved the final manuscript.

\section{REFERENCES}

1. Zhu Y, Zhang C. Prevalence of gestational diabetes and risk of progression to type 2 diabetes: a global perspective. Curr Diab Rep. (2016) 16:111. doi: 10.1007/s11892-015-0699-x

2. Page KA, Luo S, Wang X, Chow T, Alves J, Buchanan TA, et al. Children exposed to maternal obesity or gestational diabetes mellitus during early fetal development have hypothalamic alterations that predict future weight gain. Diabetes Care. (2019) 42:1473-80. doi: 10.2337/dc18-2581

3. Farrar D, Simmonds M, Bryant M, Sheldon TA, Tuffnell D, Golder S, et al. Hyperglycaemia and risk of adverse perinatal outcomes: systematic review and meta-analysis. BMJ. (2016) 354:i4694. doi: 10.1136/bmj.i4694

4. Lowe WL, Scholtens DM, Kuang A, Linder B, Lawrence JM, Lebenthal $\mathrm{Y}$, et al. Hyperglycemia and adverse pregnancy outcome follow-up study (HAPO FUS): maternal gestational diabetes mellitus and childhood glucose metabolism. Diabetes Care. (2019) 42:372-80. doi: 10.2337/dc18-1646

5. Agha-Jaffar R, Oliver N, Johnston D, Robinson S. Gestational diabetes mellitus: does an effective prevention strategy exist? Nat Rev Endocrinol. (2016) 12:533-46. doi: 10.1038/nrendo.2016.88

6. Mandaviya PR, Joehanes R, Brody J, Castillo-Fernandez JE, Dekkers KF, Do AN, et al. Association of dietary folate and vitamin B-12 intake with genome-wide DNA methylation in blood: a large-scale epigenome-wide association analysis in 5841 individuals. Am J Clin Nutr. (2019) 110:43750. doi: 10.1093/ajen/nqz031

7. Singh MD, Thomas P, Owens J, Hague W, Fenech M. Potential role of folate in pre-eclampsia. Nutr Rev. (2015) 73:694-722. doi: 10.1093/nutrit/nuv028

8. Czeizel AE. Is folic acid a risk factor for oral clefts? Eur J Epidemiol. (2013) 28:841-3. doi: 10.1007/s10654-013-9862-3

9. Burdge GC, Lillycrop KA. Folic acid supplementation in pregnancy: are there devils in the detail? Br J Nutr. (2012) 108:1924-30. doi: 10.1017/S0007114512003765

10. Zhu B, Ge X, Huang K, Mao L, Yan S, Xu Y, et al. Folic acid supplement intake in early pregnancy increases risk of gestational diabetes mellitus: evidence from a prospective cohort study. Diabetes Care. (2016) 39:e367. doi: $10.2337 / \mathrm{dc} 15-2389$

11. Li M, Li S, Chavarro JE, Gaskins AJ, Ley SH, Hinkle SN, et al. Prepregnancy habitual intakes of total, supplemental, and food folate and risk of gestational diabetes mellitus: a prospective cohort study. Diabetes Care. (2019) 42:103441. doi: $10.2337 / \mathrm{dc} 18-2198$

12. Kouroglou E, Anagnostis P, Daponte A, Bargiota A. Vitamin B12 insufficiency is associated with increased risk of gestational diabetes

\section{SUPPLEMENTARY MATERIAL}

The Supplementary Material for this article can be found online at: https://www.frontiersin.org/articles/10.3389/fnut.2021. 670289/full\#supplementary-material

Supplementary Figure 1 | Funnel plot for the meta-analysis serum folate concentration during pregnancy between GDM and non-GDM groups.

Supplementary Figure 2 | Funnel plot for the meta-analysis of serum vitamin B12 concentration during pregnancy between GDM and non-GDM groups.

Supplementary Figure 3 | Funnel plot for the meta-analysis of adjusted odds ratios assessing relationship between GDM and RBC folate (as continuous variable).

Supplementary Figure 4 | Funnel plot for the meta-analysis of adjusted odds ratios assessing relationship between GDM and serum folate (as continuous variable).

Supplementary Figure 5 | Meta-analysis of adjusted odds ratios assessing relationship between GDM and vitamin B12 (as continuous variable).

Supplementary Table 1 | Search strategy and results of PubMed database. Supplementary Table 2| Risk of bias analysis.

mellitus: a systematic review and meta-analysis. Endocrine. (2019) 66:14956. doi: 10.1007/s12020-019-02053-1

13. Chen X, Zhang Y, Chen H, Jiang Y, Wang Y, Wang D, et al. Association of maternal folate and vitamin B 12 in early pregnancy with gestational diabetes mellitus: a prospective cohort study. Diabetes Care. (2021) 44:21723. doi: $10.2337 / \mathrm{dc} 20-1607$

14. Moher D, Liberati A, Tetzlaff J, Altman DG, PRISMA Group. Preferred reporting items for systematic reviews and meta-analyses: the PRISMA statement. PLoS Med. (2009) 6:e1000097. doi: 10.1371/journal.pmed.1000097

15. Kim SY, Park JE, Lee YJ, Seo H-J, Sheen S-S, Hahn S, et al. Testing a tool for assessing the risk of bias for nonrandomized studies showed moderate reliability and promising validity. J Clin Epidemiol. (2013) 66:40814. doi: 10.1016/j.jclinepi.2012.09.016

16. Wan X, Wang W, Liu J, Tong T. Estimating the sample mean and standard deviation from the sample size, median, range and/or interquartile range. BMC Med Res Methodol. (2014) 14:135. doi: 10.1186/1471-2288-14-135

17. Seghieri G, Breschi MC, Anichini R, De Bellis A, Alviggi L, Maida I, et al. Serum homocysteine levels are increased in women with gestational diabetes mellitus. Metabolism. (2003) 52:720-3. doi: 10.1016/S0026-0495(03)00032-5

18. Tarim E, Bagis T, Kilicdag E. Elevated plasma homocysteine levels in gestational diabetes mellitus. Acta Obstet Gynecol Scand. (2005) 84:3067. doi: 10.1111/j.0001-6349.2005.0719b.x

19. Guven MA, Kilinc M, Batukan C, Ekerbicer HC, Aksu T. Elevated second trimester serum homocysteine levels in women with gestational diabetes mellitus. Arch Gynecol Obstet. (2006) 274:333-7. doi: 10.1007/s00404-006-0191-6

20. Krishnaveni GV, Hill JC, Veena SR, Bhat DS, Wills AK, Karat CLS, et al. Low plasma vitamin B12 in pregnancy is associated with gestational "diabesity" and later diabetes. Diabetologia. (2009) 52:2350-8. doi: 10.1007/s00125-009-1499-0

21. Idzior-Waluś B, Cyganek K, Sztefko K, Seghieri G, Breschi MC, Waluś-Miarka $\mathrm{M}$, et al. Total plasma homocysteine correlates in women with gestational diabetes. Arch Gynecol Obstet. (2008) 278:309-13. doi: 10.1007/s00404-008-0571-1

22. Sukumar N, Venkataraman H, Wilson S, Goljan I, Selvamoni S, Patel $\mathrm{V}$, et al. Vitamin B12 status among pregnant women in the UK and its association with obesity and gestational diabetes. Nutrients. (2016) 8:768. doi: $10.3390 /$ nu8120768

23. Lai JS, Pang WW, Cai S, Lee YS, Chan JKY, Shek LPC, et al. High folate and low vitamin B12 status during pregnancy is associated with gestational diabetes mellitus. Clin Nutr. (2018) 37:940-7. doi: 10.1016/j.clnu.2017.03.022 
24. Xie K, Xu P, Fu Z, Gu X, Li H, Cui X, et al. Association of maternal folate status in the second trimester of pregnancy with the risk of gestational diabetes mellitus. Food Sci Nutr. (2019) 7:3759-65. doi: 10.1002/fsn3.1235

25. Li S, Hou Y, Yan X, Wang Y, Shi C, Wu X, et al. Joint effects of folate and vitamin B12 imbalance with maternal characteristics on gestational diabetes mellitus. J Diabetes. (2019) 11:744-51. doi: 10.1111/1753-0407.12899

26. Jankovic-Karasoulos T, Furness DL, Leemaqz SY, Dekker GA, Grzeskowiak LE, Grieger JA, et al. Maternal folate, one-carbon metabolism and pregnancy outcomes. Matern Child Nutr. (2020) 17:e13064. doi: 10.1111/mcn.13064

27. Liu PJ, Liu Y, Ma L, Yao AM, Chen XY, Hou YX, et al. Associations between gestational diabetes mellitus risk and folate status in early pregnancy and mthfr C677T polymorphisms in Chinese Women. Diabetes Metab Syndr Obes Targets Ther. (2020) 13:1499-507. doi: 10.2147/DMSO.S250279

28. Blencowe H, Cousens S, Modell B, Lawn J. Folic acid to reduce neonatal mortality from neural tube disorders. Int J Epidemiol. (2010) 39:111021. doi: $10.1093 / \mathrm{ije} / \mathrm{dyq} 028$

29. Calonge N, Petitti DB, DeWitt TG, Dietrich AJ, Gregory KD, Grossman D. Folic acid for the prevention of neural tube defects: U.S. Preventive services task force recommendation statement. Ann Intern Med. (2009) 150:626-31. doi: 10.7326/0003-4819-150-9-200905050-00009

30. Yajnik CS, Deshpande SS, Jackson AA, Refsum H, Rao S, Fisher DJ, et al. Vitamin B12 and folate concentrations during pregnancy and insulin resistance in the offspring: the Pune Maternal Nutrition Study. Diabetologia. (2008) 51:29-38. doi: 10.1007/s00125-007-0793-y

31. Milman N. Intestinal absorption of folic acid-new physiologic \& molecular aspects. Indian J Med Res. (2012) 136:725-8.

32. Anderson CAM, Beresford SAA, Mclerran D, Lampe JW, Deeb S, Feng $Z$, et al. Response of serum and red blood cell folate concentrations to folic acid supplementation depends on methylenetetrahydrofolate reductase C677T genotype: results from a crossover trial. Mol Nutr Food Res. (2013) 57:637-44. doi: 10.1002/mnfr.201200108

33. Cordero AM, Crider KS, Rogers LM, Cannon MJ, Berry RJ. Optimal serum and red blood cell folate concentrations in women of reproductive age for prevention of neural tube defects: World Health Organization guidelines. MMWR Morb Mortal Wkly Rep. (2015) 64:421-3.
34. Clarke R, Grimley Evans J, Schneede J, Nexo E, Bates C, Fletcher A, et al. Vitamin B12 and folate deficiency in later life. Age Ageing. (2004) 33:3441. doi: 10.1093/ageing/afg109

35. Looman M, Geelen A, Samlal RAK, Heijligenberg R, Klein Gunnewiek JMT, Balvers MGJ, et al. Changes in micronutrient intake and status, diet quality and glucose tolerance from preconception to the second trimester of pregnancy. Nutrients. (2019) 11:460. doi: 10.3390/nu110 20460

36. Costantine MM. Physiologic and pharmacokinetic changes in pregnancy. Front Pharmacol. (2014) 5:65. doi: 10.3389/fphar.2014.00065

37. Zheng LD, Linarelli LE, Liu L, Wall SS, Greenawald MH, Seidel $\mathrm{RW}$, et al. Insulin resistance is associated with epigenetic and genetic regulation of mitochondrial DNA in obese humans. Clin Epigenetics. (2015) 7:60. doi: 10.1186/s13148-015-0093-1

38. Troen AM, Mitchell B, Sorensen B, Wener MH, Johnston A, Wood B, et al. Unmetabolized folic acid in plasma is associated with reduced natural killer cell cytotoxicity among postmenopausal women. J Nutr. (2006) 136:18994. doi: 10.1093/jn/136.1.189

39. Zhao YH, Wang DP, Zhang LL, Zhang F, Wang DM, Zhang WY. Genomic expression profiles of blood and placenta reveal significant immune-related pathways and categories in Chinese women with gestational diabetes mellitus. Diabet Med. (2011) 28:237-46. doi: 10.1111/j.1464-5491.2010.0 3140.x

Conflict of Interest: The authors declare that the research was conducted in the absence of any commercial or financial relationships that could be construed as a potential conflict of interest.

Copyright (c) 2021 Wang, Hou, Meng, Yang, Meng and Liu. This is an open-access article distributed under the terms of the Creative Commons Attribution License (CC $B Y)$. The use, distribution or reproduction in other forums is permitted, provided the original author(s) and the copyright owner(s) are credited and that the original publication in this journal is cited, in accordance with accepted academic practice. No use, distribution or reproduction is permitted which does not comply with these terms. 